\title{
Assessment of Heavy Metal in Raw Meat Sold in Some Notable Garages in Ogun State, South West, Nigeria
}

\author{
MAKANJUOLA, Olakunle Moses \\ Dept of Food Technology, Federal Polytechnic, Ilaro, Ogun State, Nigeria
}

\begin{abstract}
In this work, heavy metals such as $\mathrm{Fe}, \mathrm{Zn}, \mathrm{Cu}, \mathrm{Ni}, \mathrm{Cd}, \mathrm{Pb}, \mathrm{Cr}, \mathrm{Hg}$, As and $\mathrm{Mn}$ in raw meat sold in some garages in Ogun State, South West, Nigeria were determined using atomic absorption spectrophotometry method. Various concentrations of these metals were obtained after subjecating the results to statistical analysis using SPSS statistical software. The heavy metals evaluated in the investigated samples indicated the following range of concentration: $\mathrm{Fe}: 3.36-4.81 \mathrm{mg} / \mathrm{k} ; \mathrm{Zn}: 1.62-3.83 \mathrm{mg} / \mathrm{kg} ; \mathrm{Cu}: 0.55-1.22 \mathrm{mg} / \mathrm{kg} ; \mathrm{Ni}: 0.01-0.56 \mathrm{mg} / \mathrm{kg} ; \mathrm{Mn}$ : $1.27-1.42 \mathrm{mg} / \mathrm{kg} ; \mathrm{Pb}: 0.01-0.02 \mathrm{mg} / \mathrm{kg}$. Cd had $0.01 \mathrm{mg} / \mathrm{kg}$ in three of the samples while $\mathrm{Cr}, \mathrm{Hg}$ and As were undetectable as their concentrations were lower than detection limits. Some samples containing level of Cu and $\mathrm{Ni}$ above permissible limits are alarming and therefore should be regularly examined for public health concern. Generally, most of the raw meat samples analyzed are relatively safe and not contaminated by heavy metals
\end{abstract}

Keyword: Assessment, Heavy metal, meat, garages.

\section{INTRODUCTION}

Meat is animal flesh that is eaten as food (1). The adverse of civilization allowed the domestication of animals such as chicken, sheep, fish, seafood, pig and cattle and eventually their use in meat production on an industrial scale. Meat and meat products form an important part of human diet as well as important source of wide range of nutrients, but they may also carry certain toxic substances. Meat is essential for growth and maintenance of good health and mainly composed of protein, fat, carbohydrate water, vitamins and minerals. (2).

Heavy metals from manmade pollution sources are continuously released into aquatic and terrestrial ecosystem and therefore, the concern about the effect of anthropogenic pollution on the ecosystem is growing (3). Contamination with heavy metals is a serious threat because of their toxicity, bioaccumulation and bio-magnifications in the food chain $(3,4)$. Heavy metals are toxic in nature and even at relatively lower concentration can cause adverse effect (5). Processing of meat and rearing of livestock in proximity to polluted surroundings are the key factors for their pollutions in meat (6).

Contamination of meat can also be caused by vehicle emission and from dirty slaughter place. Toxic metal is defined as that metal, which is neither essential nor has a beneficial effect, on the contrary, it displays severe toxicological symptoms at low levels and it is defined as metal with a specific weight more than $5 \mathrm{~g} / \mathrm{cm}^{3}$. With increasing industrialization, more and more metals are entering into the environment $(7,8)$. The ingestion of food is an obvious means of exposure to metals, not only because many metals are natural components of food stuff but also because of environmental contamination and contamination during processing $(8,9)$. The objective of this work is to find out the levels of some heavy metals in raw meat sold in some garages in Ogun State, South West, Nigeria and relate them to the maximum permissible levels specified by international bodies

\section{Materials ANd Methods}

Source of materials: Raw meat samples were purchased from different garages whose heavy vehicular pollution are abundant. The meat samples were collected in polyethylene bags, properly labeled for easy identification and kept in the refrigerator prior to analyses. The reagents used were of analytical grade.

\subsection{METHODS}

The digestion of the samples for the determination of the heavy metals was carried out following the method described in a previous work (3), using a mixture of $\mathrm{HNO}_{3}, \mathrm{HCLO}_{4}$ and hydrogen peroxide 
$\left(\mathrm{H}_{2} \mathrm{O}_{2}\right)$. The sample $(2.00 \mathrm{~g})$ placed in a digestion tube, were predigested in $10 \mathrm{ml}$ concentrated $\mathrm{HNO}_{3}$ at $135^{\circ} \mathrm{C}$ until the liquor was clear. Next, $10 \mathrm{ml}$ of $\mathrm{HNO}_{3}, 1 \mathrm{ml} \mathrm{HCLO}_{4}$ and $2 \mathrm{ml} \mathrm{H}_{2} \mathrm{O}$ were added and temperature was maintained at $135^{\circ} \mathrm{C}$ for $1 \mathrm{hr}$ until the liquor became colorless. The digest was slowly evaporated to near dryness (avoiding prolonged baking), cooled and dissolved in $1 \mathrm{M} \mathrm{HNO}_{3}$. The digests were subsequently filtered through What man filter No1 and diluted to $25 \mathrm{ml}$ with $1 \mathrm{M} \mathrm{HNO}_{3}$. The content of heavy metals in the sample solution was analyzed using air acetylene flame atomic absorption spectrophotometer (spectr. AA 220, Australia). In all metal determinations, analytical blanks were prepared in a similar manner

Statistical analyses of result were performed using SPSS statistical software

\section{RESUlTS AND DiscuSSiON}

\subsection{Result}

Table1. Heavy metals concentration $(\mathrm{mg} / \mathrm{kg})$ in Raw meat samples obtained from Garages in Ogun State, South West, Nigeria

\begin{tabular}{|l|l|l|l|l|l|}
\hline Heavy metal & A & B & C & D & E \\
\hline Iron $(\mathrm{Fe}) \mathrm{mg} / \mathrm{kg}$ & $3.36 \pm 0.046$ & $4.81 \pm 0.014$ & $3.46 \pm 0.028$ & $3.82 \pm 0.035$ & $3.75 \pm 0.014$ \\
\hline Zinc $(\mathrm{Zn}) \mathrm{mg} / \mathrm{kg}$ & $3.83 \pm 0.035$ & $1.95 \pm 0.014$ & $2.05 \pm 0.071$ & $1.91 \pm 0.014$ & $1.62 \pm 0.092$ \\
\hline Copper $(\mathrm{Cu}) \mathrm{mg} / \mathrm{kg}$ & $1.22 \pm 0.028$ & $0.55 \pm 0.778$ & $0.80 \pm 0.063$ & $0.95 \pm 0.021$ & $1.15 \pm 0.566$ \\
\hline Nickel $(\mathrm{Ni}) \mathrm{mg} / \mathrm{kg}$ & $0.01 \pm 0.001$ & $0.56 \pm 0.792$ & $\mathrm{ND}$ & $0.01 \pm 0.001$ & $0.01 \pm 0.001$ \\
\hline Cadonium $(\mathrm{Cd}) \mathrm{mg} / \mathrm{kg}$ & $0.01 \pm 0.001$ & $\mathrm{ND}$ & $\mathrm{ND}$ & $0.01 \pm 0.01$ & $0.01 \pm 0.001$ \\
\hline Lead (Pb)mg/kg & $0.02 \pm 0.005$ & $\mathrm{ND}$ & $\mathrm{ND}$ & $0.01 \pm 0.001$ & $0.01 \pm 0.001$ \\
\hline Chromium(Cr)mg/kg & $\mathrm{ND}$ & $\mathrm{ND}$ & $\mathrm{ND}$ & $\mathrm{ND}$ & $\mathrm{ND}$ \\
\hline Mercury $(\mathrm{Hg}) \mathrm{mg} / \mathrm{kg}$ & $\mathrm{ND}$ & $\mathrm{ND}$ & $\mathrm{ND}$ & $\mathrm{ND}$ & $\mathrm{ND}$ \\
\hline Arsenic $(\mathrm{As}) \mathrm{mg} / \mathrm{kg}$ & $\mathrm{ND}$ & $\mathrm{ND}$ & $\mathrm{ND}$ & $\mathrm{ND}$ & $\mathrm{ND}$ \\
\hline Manganese $(\mathrm{Mn}) \mathrm{mg} / \mathrm{kg}$ & $1.34 \pm 0.056$ & $1.27 \pm 0.014$ & $1.42 \pm 0.028$ & $1.42 \pm 0.028$ & $1.42 \pm 0.028$ \\
\hline
\end{tabular}

Key: $N D \rightarrow$ Not detected, $A \rightarrow$ Ilaro garage, $B \rightarrow$ Papalanto garage, $C \rightarrow$ Ifo garage, $D \rightarrow$ Sango-ota garage $E \rightarrow$ Ita osin garage

\subsection{Discussion}

The results for the assessment of heavy metals in $\mathrm{mg} / \mathrm{kg}$ are shown in Table 1 . Iron concentration in the raw meat analyzed ranged from $3.36 \mathrm{mg} / \mathrm{kg}$ to $4.81 \mathrm{mg} / \mathrm{kg}$ for all the samples being investigated. It appears that there was a low content of Fe in all the samples. FAO/WHO (10) recommends that iron intake in meat should not exceed $48 \mathrm{mg} / \mathrm{kg}$ per day. The levels of $\mathrm{Fe}$ in all the samples are lower than those reported in a previous work $(3,11)$. Low level of Fe in the body is the most common cause of anemia, known as iron-deficiency anemia while overdose can lead to nausea, vomiting, abdominal pain, diarrhea and possible gastro-intestinal bleeds.

Zinc is an essential trace element for animal, being involved in protein synthesis and as a constituent of many metallo enzymes. $(11,12)$. The level of Zinc in the samples varied from $1.62 \mathrm{mg} / \mathrm{kg}$ to 3.82 $\mathrm{mg} / \mathrm{kg}$. The zinc levels are extremely low when compared to a related work (3) and FAO/WHO (10) recommendation of $25 \mathrm{mg} / \mathrm{kg}$ per day.

The concentration of copper was found to range from $0.80 \mathrm{mg} / \mathrm{kg}$ to $1.22 \mathrm{mg} / \mathrm{kg}$ in the meat samples. Copper is essential component of various enzymes and it plays a key role in bone formation, skeletal and mineralization and in maintaining the integrity of the connective tissue. Very high intake can cause health problems such as liver and kidney damage (13). FAO/WHO (10) recommends that copper intake should not exceed $1.0 \mathrm{mg} / \mathrm{kg}$ per day. The levels of copper obtained in this work are similar to those reported in the literature (3).

As reported in the literature (3), Nickel (Ni) can cause respiratory problem and is a carcinogen $(3,13$, 14 ). Nickel concentrations in all the meat samples are between $0.01 \mathrm{mg} / \mathrm{kg}$ and $0.56 \mathrm{mg} / \mathrm{kg}$. The level of intake of Nickel (Ni) as recommended by FAO/WHO (10) should not exceed $0.2 \mathrm{mg} / \mathrm{kg}$ per day. The amount of nickel found in this present work is higher in one of the meat samples obtained from one of the garages and this call for a concern. Cadmium (Cd) was found in $60 \%$ (3 samples) of the meat samples being evaluated, with $0.01 / \mathrm{mg} / \mathrm{kg}$. Cadmium is toxic to virtually every system in the body. It is absent in human body at birth. However, it accumulates with age. It is reported that cadmium can affect bone metabolism in both industrial and people exposed to cadmium in general environment (15). FAO/WHO (10) recommends than the daily intake of cadmium in meat should not exceed $0.05 \mathrm{mg} / \mathrm{kg}$ per day. 
The concentration of lead in the raw meat sample has a similar pattern detected for cadmium. The levels ranged from $0.01 \mathrm{mg} / \mathrm{kg}$ to $0.02 \mathrm{mg} / \mathrm{kg}$. According to literature $(3,16)$, excess lead is known to reduce the, congnitive development and intellectual performance in children and to increase blood pressure and cardiovascular disease incidence in adults. The level of lead is lower when compared to $0.2 \mathrm{mg} / \mathrm{kg} / \mathrm{day}$ recommended by $\mathrm{FAO} / \mathrm{WHO}(10)$.

Manganese concentration in the raw meat sample analyzed varied from $1.27 \mathrm{mg} / \mathrm{kg}$ to $1.42 \mathrm{mg} / \mathrm{kg}$. Manganese ions function as cofactor for a large variety of enzymes and are particularly essential in detoxification of superoxide free radicals in organisms that must deal with elemental oxygen.

The elements chromium, mercury and arsenics were undetectable, as their concentrations were lower than the detection limit. These three elements are also essential, though at low concentration in human body, for example, chromium functions as cofactor of insulin when in trace amount but could be toxic when it exceeds the tolerable limit (17).

\section{CONCLuSion}

The concentrations of most of the heavy metal analyzed in the raw meat samples were lower than the permissible limits recommended by FAO/WHO, except in few cases. Therefore, it can be concluded that the samples analyzed are relatively safe and not contaminated by heavy metals. Hence, meat sold around major garages found in Ogun State, South West, Nigeria are fit for consumption.

\section{REFERENCES}

[1] Lawrie, R.A and Ledward, D.A (2006): Lawrie meat science $7^{\text {th }}$ edn. Cambridge wood head Publishing Ltd. ISBN 978-1-84560-159-2.

[2] Bayko, B.D Stoyanov, M.P and Guyova (1996): Cadmium and Lead bioaccumulation in male chickens for high food concentration. Toxicol. Environ. Chem.: 54:155-159

[3] Iwegbue, C.M.A, Nwajei, G.E and Iyoha, E.H (2008): Heavy metal residues of chicken meat and gizzard and Turkey meat consumed in Southern Nigeria. Bulgarian Journal of Veterinary Medicine. 11 (4): 275-280.

[4] Demirezen, O and Uruc, K (2006): Comparative study of trace elements in certain fish, meat and meat products. Food chemistry. 32: 215-222

[5] Santhi, D.v, Balakrishma, D, Kalaikannan, A and Radhakrishman, K.T (2008): Prescence of heavy metals in pork product in Chennai (India). Am. J. food. Technol. 3(3): 192-199.

[6] Sodki, A, Lekoch, N, Gannon, S and Pineaw, A (2003): Toxic and essential trace element in muscle, liver and kidney of bovines from a polluted area of Morocco. Science of the total environment. 317:201-205.

[7] Akan, J.C, Abdulrahman, F.I, Sodipo, O.A and Chiroma, Y.A. (2010). Distribution of heavy metals in liver, kidney and meet of beef, mutton, caprine and chicken from kasuwan shanu market in Maiduguri metropolis, Borno state, Nigeria. Journal of Applied Science, Engineering and Technology. 2(8): 743-748.

[8] Areej, Kh, A, Angham, O.Z, and Adem, A.A (2008): Determination of Mercury, Nickel and Copper in some types of canned fish and meat. Bas. J. Vet. Res. 11(2): 1-9.

[9] Yousuf, M,H,A, and EL-Shahawi, M.S (1999): Trace metals in lethrinus lentian fish from Arabian Gulf: Metal accumulation in kidney and heart tissues. Bulletin of Environmental Contamination and Toxicology. 62: 293-300.

[10] FAO/WHO (2001): Joint FAO/WHO Food Standards Program, Codex Committee of Food Additives and contaminants, Thirty-third session. The mother laws; 12-16 March.

[11] Chowdhury, M. Z. A, Siddique, Z.A, Hossain, S. M. A, Kazl, A.I, Ahson, M. A, Ahmed, S and Mahbubzaman, M (2011): Determination of essential and toxic metal in meat, meat products and egg by Spectrophotometric method. Journal of Bangladesh chemical. Society. 24(2): 165-172.

[12] Underwood, E.J. (1977): Trace elements in human and animals nutrition. $4^{\text {th }}$ edition. Academic press, New york.

[13] ATSDR (2004): Agency for Toxic Substance and Disease Registry. Division of Toxicology, Cliffon road, Atlanta. Rectrieved from http://www. Atsdr.edc.gov/toxprofiles. 
[14] Anonymous (2003): Dietary reference intake: Application in dietary planning. Subcommittee on interpretation and uses of dietary reference intake and the standing committee on the scientific evaluation of dietary reference intakes. Institute of medicine of National Academies, the National Academies Press. Washington D.C: 248.

[15] Jarup, L, Berglund, M, Elinder, C.G and Nordberg, G (1998): Health effects of cadmium exposure: A review of the literature and a risk estimate. Scand. J. Work Environ. Health.24 (1) : $1-51$.

[16] Anonymous (2001a): Commission of the European Communities. Commission Regulation (EC) No 221/2002 of February 2002 amending regulation (EC) No 466/2002 setting maximum levels for certain contaminants in food stuffs. Official Journal of the European Communities, Brussels. 6 February 2002.

[17] Khurshid, J.S and Igbal, H.Q (1994): The role of inorganic elements in the human body. Nucleus. 2: 280-284. 